CASE REPORT

\title{
Palliative Re-Irradiation of Bone Metastases - Case Report
}

\author{
Dragos Petru Teodor IANCU1,2, Ovidiu Nicolae PAGUTE³ ${ }^{3}$ Cosmin SAFTA ${ }^{3}$, Camil Ciprian MIRESTEAN ${ }^{4}$, \\ Roxana Irina IANCU1,4
}

\begin{abstract}
Bone metastasis is a severe complication of malignant tumors. Management of multiple bone metastases remains difficult and prognosis is generally unfavorable, radiotherapy being often the therapeutic option. The main goals of the palliative irradiation of bone metastases are the reduction of pain intensity and the decreasing the analgesic dose used. Overall survival of patients with oligometastatic disease for hormone dependent cancers like breast and prostate may exceed three years and for these groups of patients the reduction of the associated tardive toxicity after irradiation is essential for preserving the quality of life. We present the case of a patient diagnosed in March 2011 with prostate cancer, multiple bone metastases in November 2012. In December 2012, palliative radiotherapy was administrated in a total dose of $21 \mathrm{~Gy} /$ fractions, weekly in the lumbosacral region. Seven years after the first presented an increase in pain intensity in the left ischio-pubian branch and pubic symphysis and the bone scintigraphy reveal the progression of the metastatic disease. Palliative re-irradiation was administrated in total dose of 20Gy/5fractions in painful region. Re-irradiation for bone metastasis remains a therapeutic option with the potential to reduce the pain. Image guided radiotherapy can reduce the risk of late toxicity, especially for long-term survivors.
\end{abstract}

Keywords: radiotherapy, re-irradiation, bone metastases, palliative.

\section{Rezumat}

Metastaza osoasă este o complicație severă a tumorilor maligne. Gestionarea metastazelor osoase multiple rămâne dificilă, iar prognosticul este în general nefavorabil, radioterapia fiind adesea opțiunea terapeutică. Principalele obiective ale iradierii paliative ale metastazelor osoase sunt reducerea intensității durerii și scăderea dozei de analgezic utilizate. Supraviețuirea globală a pacienților cu boală oligometastatică pentru cancerele dependente de hormoni, cum ar fi cancerul de sân și de prostată, poate depăși trei ani, iar pentru aceste grupuri de pacienți, reducerea toxicității tardive asociate după iradiere este esențială pentru păstrarea calității vieții. Prezentăm cazul unui pacient diagnosticat în martie 2011 cu cancer de prostată, metastaze osoase multiple în noiembrie 2012. În decembrie 2012, radioterapia paliativă a fost administrată într-o doză totală de 21 Gy / fracțiuni, săptămânal în regiunea lombosacrală. La șapte ani după prima prezentare a crescut intensitatea durerii în ramura ischio-pubiană stângă și simfiza pubiană și scintigrafia osoasă dezvăluie progresia bolii metastatice. Re-iradierea paliativă a fost administrată în doza totală de 20Gy / 5 fracțiuni în regiunea dureroasă. Reiradierea pentru metastaza osoasă rămâne o opțiune terapeutică cu potențialul de a reduce durerea. Radioterapia modern, ghidată imagistic poate reduce riscul de toxicitate tardivă, în special pentru supraviețuitorii pe termen lung.

Cuvinte cheie: radioterapie, re-iradiere, metastaze osoase, paliativ.

\footnotetext{
${ }^{1}$ "Gr. T. Popa" University of Medicine and Pharmacy, lasi, Romania

${ }^{2}$ Regional Institute of Oncology, lasi, Romania

${ }^{3}$ MedEuropa Radiotherapy Center, Constanta, Romania

${ }^{4}$ University of Medicine and Pharmacy of Craiova, Romania

${ }^{5}$ „St. Spiridon" Emergency University Hospital, Iasi, Romania
}

\section{Corresponding author.}

C.C. MIRESTEAN, University of Medicine and Pharmacy of

Craiova, Romania.

E-mail: mc3313@yahoo.com 
Bone metastases (BM) represent a frequent and severe complication of advanced prostate neoplasms associated with skeletal events, pain and hypercalcemia, causing deterioration of quality of life. Vertebroplasty and kyphoplasty are used to treat painful vertebral compression, fractures in the column, and along with bisphosphonates and radionuclides have improved prognosis and survival in these patients. Radiotherapy remains a cornerstone in the treatment of symptoms, providing not only a long-term reducer of pain but also provides vertebral stability and reduces the risk for pathological bone fracture. The use of a second irradiation of a painful bone metastasis can be considered, in generally, providing moderate pain relief, regardless the response of the first radiation therapy course. It is generally preferable to irradiate peripheral metastases if the recommended dose limits for healthy tissue are achieved $^{1,2}$.

Androgen deprivation treatment (ADT) is the gold standard for the treatment of metastatic prostate cancer. Although $85 \%$ of the hormone naive patients respond to ADT by reducing pain intensity, metastatic regression, and decrease of prostate specific antigen (PSA), median survival for patients with metastatic prostate cancer is 30-49 months. Some authors appreciate a benefit in survival by adding prostate or pelvic radiotherapy to $\mathrm{ADT}$ even at the metastatic stage. Using the single $8 \mathrm{~Gy}$ fraction scheme seems to have the same effect in pain relief as multiple fractionation regimens. The most commonly used radiotherapy regimens used for pain relief caused by the bone metastases are $30 \mathrm{~Gy}$ delivered in 10 fractions, 20Gy in 5 fractions, $24 \mathrm{~Gy}$ in 6 fractions, or regimens with one fraction per week (21Gy in 3 fractions, 3 weeks). Patients who have long-lasting survival and received a single fraction have a higher rate of retreatment (20\%) than those treated initially with multiple fractions (8\%).

\section{MATERIALS AND METHODS}

We present the case of a patient diagnosed in March 2011 with locally advanced prostate cancer. The pathology outcome based on prostatic biopsy, revealed a Gleason $7(3+4)$ acinar adenocarcinoma. After 18 months, bone scintigraphy with $99 \mathrm{mTc}$ identified multiple intense focal increased uptakes of radionuclide, suggestive for metastases in the sternum, lumbar spine, pelvis and in the proximal diaphysis of the left femur. ADT with leuprolein acetate and bisphosphonate therapy were initiated (Figure 1).

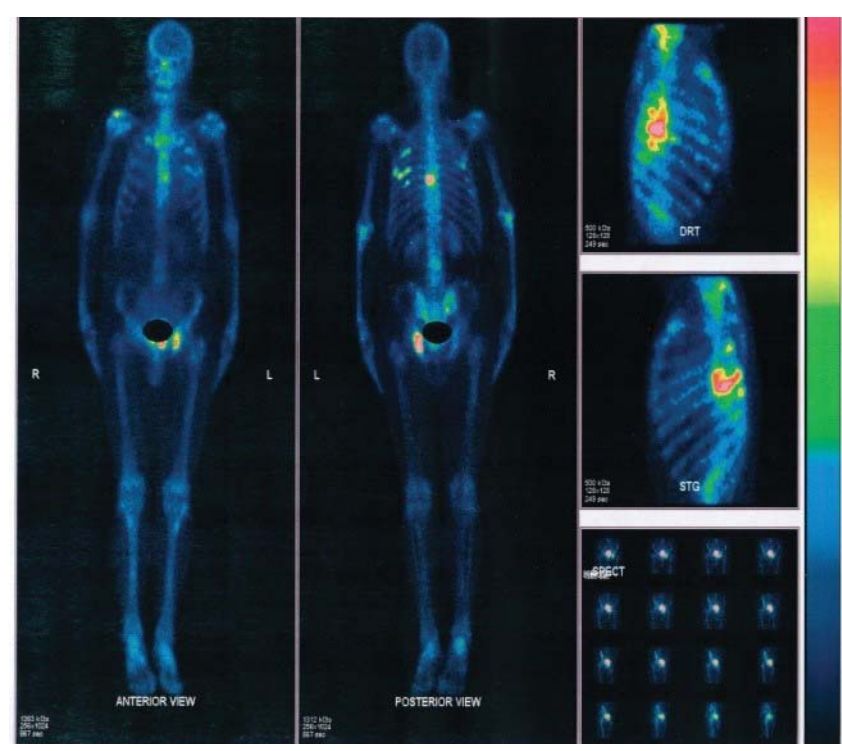

Figure 1. Whole-body Tc-99m MDP bone scan revealing multiple bone metastases.

Two months after the diagnosis of bone metastases, the patient experienced pain in the pelvis. Pelvic irradiation was proposed for palliative antalgic purposes. Radiation planning was performed using an Acqsim $\mathrm{CT}$ simulation scanner with $1 \mathrm{~cm}$ slice thickness.

Clinical target volume (CTV) was delineated by making an isotropic expansion in $1.5 \mathrm{~cm}$ bone tissue around the metastatic region to include microscopic disease and a $0.5 \mathrm{~cm}$ margin was added to define the planning target volume (PTV). The bladder and rectum were delineated as organs at risk (OAR) in order to evaluate the dose they received and to be removed from the irradiation field by the medical physicist. Radiotherapy was delivered using the linear Varian Cliniac $2100 \mathrm{Sc}$ accelerator using $6 \mathrm{MV}$ photons in a total dose of $21 \mathrm{~Gy} / 3$ fractions, one fraction per week. The reproducibility of the CT simulation in the treatment sessions was ensured by the use of lasers and ink tattoos on the patient's pelvis. A significant reduction in pain intensity was obtained starting from the second week of treatment. A bone scintigraphy performed 2 years after irradiation revealed the stationary aspect of bone metastases compared to the previous examination.Bone scintigraphy performed in 2018 revealed the progression of the disease (more than 3 new lesions compared to the previous examination) with moderate and intense uptake of the radiopharmaceutical in the vertebral column (T8, L3-L4 vertebrae), right sternoclavicular joint, ribs (posterior arch of the $\mathrm{C} 4-\mathrm{C} 7 \mathrm{ribs}$, $\mathrm{C} 11$ right posterior arch, $\mathrm{C} 5-\mathrm{C} 7$ lateral arch), pelvis 
(right sacroiliac joint, left ischium, left ischio-pubian branch) (Figure 2,3).

The patient presented an increase in pain intensity in the left ischio-pubian branch and pubic symphysis.

A reirradiation for painful bone metastases was proposed. Radiotherapy planning was performed using Siemens Somatom AS CT simulator with $5 \mathrm{~mm}$ thickness slices. A 3D-conformal treatment plan using MLC multilamellar collimator was implemented using treatment planning software (TPS) Varian Eclipse 10.0, after and target volumes and OARs were delineated. Reirradiation was performed using the Varian Clinac IX accelerator. The total dose was $20 \mathrm{~Gy}$ in 5 fractions, delivered in one week. The radiation dose was

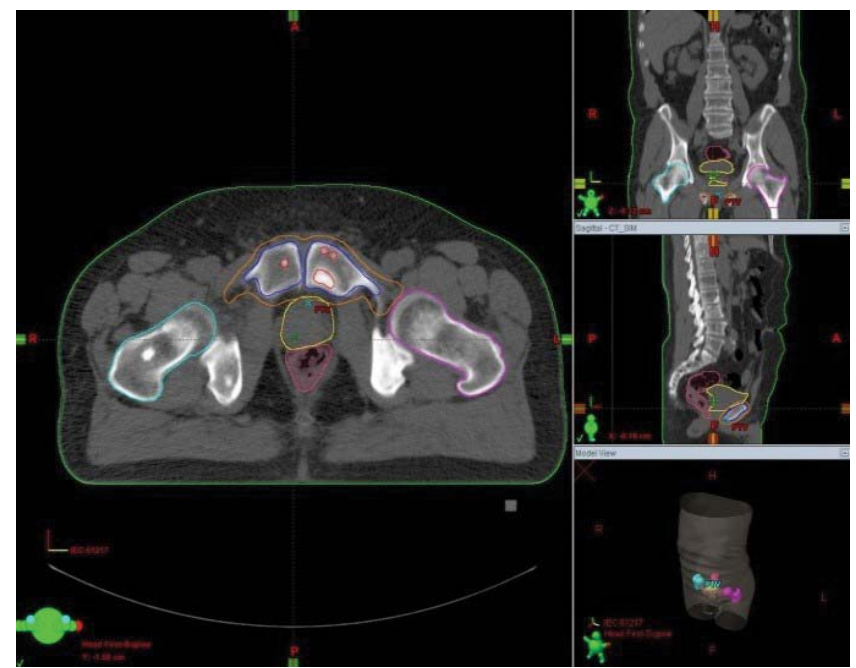

Figure 2. Target volumes and organs at risks (OARs) - Image form radiotherapy treatment planning system (TPS).

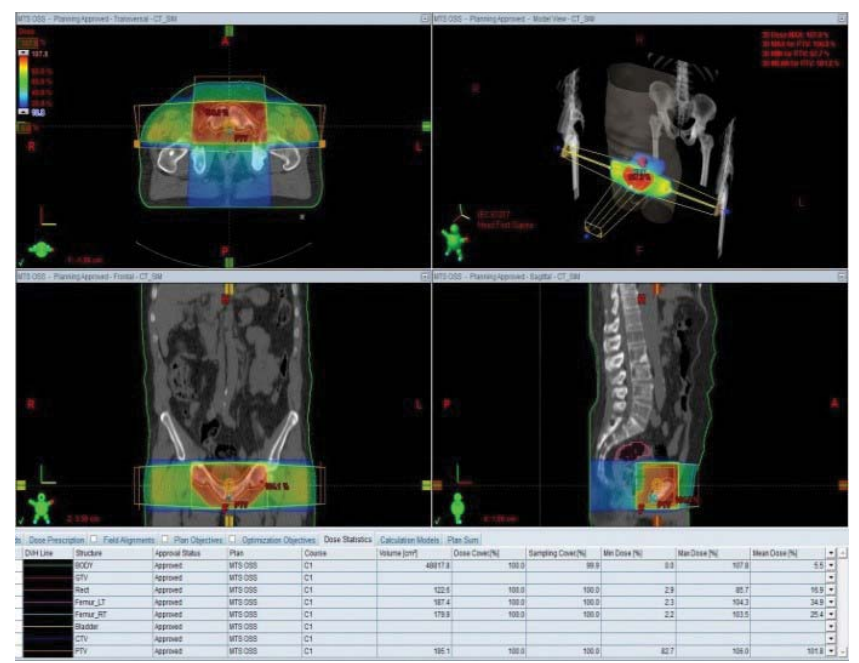

Figure 3. "Color Wash" representation of radiation dose distribution Image form radiotherapy treatment planning system (TPS). delivered to the target volume: the pubic symphysis and the ischio-pubian branch. In order to limit the acute and tardive toxicity, the dose was reduced to the organs at risk by adapting the dose using the multi-leaf collimator (MLC) and the quality of treatment delivery was assured by Varian On-Board Imager (OBI) kilovoltage $(\mathrm{kV})$ imaging systems, by overlapping the portal images with the imagines obtained from the CT simulation. Adjustment of the treatment table position reduces the dose received by healthy tissues.

\section{RESULTS AND DISCUSSIONS}

In the first week after the end of the treatment a pain flare occurred, followed by a significant reduction in pain intensity.

For patients presenting oligometastatic disease, standard fractionation regimens (40 Gy in 20 fractions or $50 \mathrm{~Gy}$ in 25 fractions) offer a survival advantage over hypofractionated regimens. The most common localizations of metastasis in prostate cancer are vertebrae and pelvis ${ }^{3}$. From the pain relief point of view, no difference was found between sngle and multiple fractions and the intensity of the effective dose response $(\mathrm{BED})^{4-6}$.

Analysis of data from 11 trials in 3435 patients with prostatic breast and prostate cancer metastases revealed an increased rate of pathological fractures after single fraction (3\%) versus only $1.6 \%$ for patients who initially received multiple fractions, the rate of spinal cord compression being identical, the authors conclude that the rate of retreatment and the risk of fracture is higher for $8 \mathrm{~Gy}$ single fraction ${ }^{7}$.

Extent of disease (EOD) observed on bone scan scintigraphy is considered a good prognostic marker of survival in $\mathrm{mPCa}$. For patients with EOD I score, defined as having less than 6 bone metastases per bone or involving less than $50 \%$ of the size of the vertebral body for each metastatic site scan, the survival at 2 years is approximately $94 \%$. For these patients the use of radiotherapy as the first option is recommended only in case of medullary compression, fracture on pathological bone or increased risk of skeletal events. Longterm ADT deprivation is associated with osteopenia / osteoporosis in $80 \%$ of the patients, and the incidence of osteoporotic fractures is $5-20 \%$. Zoledronic acid and denosumab are the systemic therapies currently recommended for the prevention of $\mathrm{mPCa}$ complications, but considering the increased risk of mandibular and 
hypocalcemic radionuclides, the treatment of longterm survivors needs to be individualized ${ }^{8,9}$.

For patients who have a long-term pain relief after radiotherapy, the time to progression is considered to be the interval between the first radiotherapy sequence and the time when increasing the analgesic dose or increasing the intensity of the pain ${ }^{10}$.

Although there is no recommended primary treatment for stage IV cancer, there is evidence that for metastatic bone cancer with a long evolution (prostate, breast), the existence of the primary tumor will contribute to the increase in metastasis. Radiotherapy can contribute by the systemic abscopal effect, the irradiation-induced inflammatory response, leading to activation of CD8 and cytotoxic T-cell ${ }^{11}$.

Re-irradiation of painful bony metastases has begun to be used frequently in the context of increasing overall patient survival due to systemic progression and surgical techniques, with $58 \%$ of these patients responding favorably.

One of the limitations of re-irradiation is the tolerance of healthy tissues at high doses of radiation. Analyzing the quality of life, the goals of palliative medicine and the economic benefits, he concluded that the palliative reassertion of painful metastasis is an option to be taken into account. There are no significant differences between the response of patients who received single fraction or multiple fractions, but patients who responded to the first irradiation seem to benefit more from retreatment ${ }^{12}$.

The same opinion is also issued by Wong et al. which complies after a systematic review, that partial and overall response rates calculated are 20\%,50\% and 68\%13.

Transient pain is described by patients in the first days after irradiation, the incidence reported by Hird et al. being between 39\% after $8 \mathrm{~Gy}$ single fraction and $41 \%$ after multiple fractions ${ }^{14}$.

The indication to perform re-irradiation of a bone metastasis is a difficult decision given the fragile balance between the clinical benefit and a risk of toxicities exacerbation. Recently, a systematic review conducted by Chow et al. demonstrated similar single fraction irradiation response rates versus multiple fractional treatment. However, in groups of patients who received irradiation, a higher proportion of 2.6 fold of patients who were initially treated with single fraction was observed. After palliative irradiation of bone metastases, the complete response rate is considered to be approximately $20 \%$ and $50 \%$ of patients have partially responded with pain relief. The benefit of re-irradiation seems to be similar to that of initial irradiation, a longer time from the first treatment and the favorable response regarding the pain relief are arguments that plead for the selection of cases using this criterion. A meta-analysis including 2694 patients proved an median benefit of $58 \%$ regarding the pain control for patients who received re-radiation at doses $\geq 4 \mathrm{~Gy}$. The most notable toxicities are gastrointestinal (18\%), while bone marrow compressions and pathological bone fractures were found in only $2 \%$ of cases. Recently, by prolonging survival with the improvement of systemic oncological therapies, considering the possibilities of reducing adverse effects by limiting the doses received by radiosensitive structures, Jeremik and collaborators proposed a second palliative reiradiation of bone metastases with a dose of 4Gy. All patients included in the study received twice a single $\geq 4 \mathrm{~Gy}$. With severe caution regarding maximum tolerance of radio-sensitive organs in the vicinity especially of the spinal cord in case of irradiation of the C5 vertebra, the authors report response rates similar to the first re-irradiation with lower rates of acute high-grade toxicity ${ }^{15-17}$.

\section{CONCLUSIONS}

Re-irradiation is a viable palliative option for patients with painful bone metastases especially for long -time survivors. The use of imaging-guided irradiation techniques can reduce toxicities which may affect the quality of life of patients.

Compliance with ethics requirements: The authors declare no conflict of interest regarding this article. The authors declare that all the procedures and experiments of this study respect the ethical standards in the Helsinki Declaration of 1975, as revised in 2008(5), as well as the national law. Informed consent was obtained from all the patients included in the study. 


\section{References}

1. Schlampp I, Rieken S, Habermehl D, Bruckner T, Förster R, Debus $\mathrm{J} H$ Rief. Stability of spinal bone metastases in breast cancer after radiotherapy: a retrospective analysis of $157 \mathrm{ca}-$ ses. Strahlenther Onkol. 2014; 190(9): 792-797. doi: 10.1007/ s00066-014-0651-z

2. De Felice F, Piccioli A, Musio D, Tombolini V. The role of radiation therapy in bone metastases management. Oncotarget. 2017 Apr 11; 8(15): 25691-25699. doi: 10.18632/oncotarget.14823

3. Peng B, Yang C, He J. Radiotherapy cannot prolong overall survival of young prostate cancer patients with bone metastases. J Transl Med. 2016; 14: 102. doi: 10.1186/s12967-016-0868-y

4. Wu JS, Wong R, Johnston M, Bezjak A, Whelan T. Meta-analysis of dose-fractionation radiotherapy trials for the palliation of painful bone metastases. Radiother Oncol. 2017 Mar;122(3):323331. doi: 10.1016/j.radonc.2016.12.031.

5. Chow R, Hoskin P, Hollenberg D, Lam M, Dennis K, Lutz S, Lam H, Mesci A, DeAngelis C, Chan S, Chow E. Efficacy of single fraction conventional radiation therapy for painful uncomplicated bone metastases: a systematic review and meta-analysis. Ann Palliat Med. 2017 Apr;6(2):125-142. doi: 10.21037/apm.2016.12.04. Epub 2017 Jan 9.

6. McQuay HJ, Collins SL, Carroll D, Moore RA. Radiotherapy for the palliation of painful bone metastases. Cochrane Database Syst Rev. 2000;(2):CD001793.

7. Sze WM, Shelley M, Held I, Mason M. Palliation of metastatic bone pain: single fraction versus multifraction radiotherapy - a systematic review of the randomised trials.Cochrane Database Syst Rev. 2004;(2):CD004721.

8. Soloway MS, Hardeman SW, Hickey D, Raymond J, Todd B, Soloway S, Moinuddin M. Stratification of patients with metastatic prostate cancer based on extent of disease on initial bone scan. Cancer. 1988 Jan 1;61(1):195-202.

9. Rosino-Sánchez A. [Preventive management of bone disease in advanced prostate cancer.] [Article in Spanish] Arch Esp Urol. 2018 Mar;71(3):258-266.

10. Tabata K, Niibe $Y$, Satoh T, Tsumura H, Ikeda M, Minamida S, Fujita T, Ishii D, Iwamura M, Hayakawa K, Baba S. Radiothe- rapy for oligometastases and oligo-recurrence of bone in prostatecancer. Pulm Med. 2012;2012:541656.

11. Yeona Cho, Jee Suk Chang, Koon Ho Rha, Sung Joon Hong, Young Deuk Choi, Won Sik Ham, Jun Won Kim, and Jaeho Cho. Does Radiotherapy for the Primary Tumor Benefit Prostate Cancer Patients with Distant Metastasis at Initial Diagnosis? PLoS One. 2016; 11(1): doi: 10.1371/journal.pone.0147191

12. Mok F, Li K, Yeung R, Wong K, Yu B, Wong E, Bedard G, Chow E. 'Who', 'when' and 'how' in re-irradiation of recurrent painful bone metastases. J Bone Oncol. 2013 Feb; 2(1): 33-37. doi: 10.1016/j.jbo.2012.12.003

13. Wong E, Hoskin P, Bedard G, Poon M, Zeng L, Lam H, Vulpe $H$, Tsao M, Pulenzas N, Chow E. Re-irradiation for painful bone metastases - a systematic review. Radiother Oncol. 2014 Jan;110(1):61-70. doi: 10.1016/j.radonc.2013.09.004.

14. Hird A, Chow E, Zhang L, Wong R, Wu J, Sinclair E, Danjoux C, Tsao M, Barnes E, Loblaw A. Determining the incidence of pain flare following palliative radiotherapy for symptomatic bone metastases: results from three canadian cancer centers. Int J Radiat Oncol Biol Phys. 2009 Sep 1;75(1):193-7. doi 10.1016/j.jijrobp.2008.10.044.

15. Nieder C, Langendijk JA, Guckenberger M, Grosu AL. Second re-irradiation: a narrative review of the available clinical data. Acta Oncol. 2018 Mar;57(3):305-310. doi: 10.1080/ 0284186X.2017.1409433

16. Jeremic B, Shibamoto Y, Igrutinovic I. Second single 4 Gy reirradiation for painful bone metastasis. J Pain Symptom Manage. 2002;23:26-30.doi: 10.1016/s0885-3924(01)00366-9.

17. Chow $E$, van der Linden $Y M$, Roos $D$, Hartsell WF, Hoskin $P$, Wu JS, Brundage MD, Nabid A, Tissing-Tan CJ, Oei B, Babington S, Demas WF, Wilson CF, Meyer RM, Chen BE, Wong RK. Single versus multiple fractions of repeat radiation for painful bone metastases: a randomised, controlled, non-inferiority trial. Lancet Oncol. 2014 Feb;15(2):164-71. doi: 10.1016/S14702045(13)70556-4. 
